\title{
変形性足関節症に対し鏡視下足関節固定術を施行した一例
}

\author{
竹 山 昭 徳* 吉 村 一 朗* 金 澤 和 貴* 内 藤 正 俊*
}

\section{A Case of Arthroscopic Arthrodesis of Ankle Joint}

\begin{abstract}
Akinori Takeyama*, Ichiro Yoshimura*, Kazuki Kanazawa*,
\end{abstract} and Masatoshi Naito*

末期変形性足関節症に対して鏡視下固定術を施行した一例を経験した。症例は足関節骨折の既往のある 55 歳男性で，当院受診時には未期変形性足関節症を呈していた．年齢，活動性を考慮し，鏡視下足関節 固定術を施行した。手術は前方の 3 portal から径 $2.7 \mathrm{~mm}$ の関節鏡を用いて行った. シェーバーで滑膜切 除を行った後に，鋭爬やアブレーダーを使用し出血が確認できるまで軟骨と軟骨下骨の掻爬を行った. 足 関節を底背屈 $0^{\circ}$, 軽度外反・外転に保持し, レントゲン透視下に $6.0 \mathrm{~mm}$ の中空スクリュー 3 本で固定し た. 術後 6 週間膝下ギプスで免荷後に荷重を開始した。術後 10 週で骨癒合が得られ，疼痛や合併症はな く良好な経過である. 諸家の報告と同様に, 変形が軽度の場合有用な治療法であると思われた.

We applied the arthroscopic technique in the treatment of ankle arthrodesis. The patient was a 55-year-old man who had previously fractured his ankle. When he visited our hospital, he had end-stage ankle arthritis. A $2.7 \mathrm{~mm}$ arthroscope and other equipment were used from anterior 3-portals. Articular cartilage and subchondral bone were removed by curetters and abraders, followed by screw fixation to maintain the neutral position. He was casted for non-weightbearing for six weeks. At 10 weeks after surgery, bony union was achieved and he had no pain and complications.

Key words : arthroscopy (関節鏡), arthrodesis (関節固定), ankle joint（足関節）, osteoarthritis (関節症)

は じめに

Schneider が 1983 年に鏡視下足関節固定術を報告 して以来，本邦でも報告が散見されるようになってき た. 今回我々は, 未期変形性足関節症に対して鏡視下 固定術を施行した一例を経験したので報告する.

\section{症例}

55 歳, 男性.

主訴：右足関節痛.

病歴：1987 年木から転落し受傷. 近医受診し, 足 関節骨折の診断で保存的加療を受けた。 その後症状な く経過していたが, 2002 年頃より右足関節痛が出現し 徐々に増強してきたため, 2005 年 6 月 2 日当科受診. 既往歴：高血圧（内服加療中）。職業：警察官（交
通取締りなどの業務).

現症：右足関節周囲に腫脹があり，疼痛性の跛行を 認めた. ROM は背屈 $0^{\circ}$, 底屈 $30^{\circ}$ と著明な可動域制 限を認めた. COT で $4 \mathrm{~cm}, \mathrm{COL}$ で $3 \mathrm{~cm}$, 健側より 小さくなっていた.

初診時のレントゲン, CT では, 脛骨・距骨の関節 裂隙はほぼ消失しており, 未期の変形性関節症を呈し ていた（図 1).

2005 年 6 月 13 日, 鏡視下足関節固定術を行った. 仰臥位でエアーターニケットを使用し，率引は Smith \& Nephew Acufex ${ }^{\circledR}$ を用いて行った。径 $2.7 \mathrm{~mm}$ の関節鏡にて前方の 3 ポータルから手術を行っ た. 鏡視を行うと, 脛骨天蓋と距骨ドーム部にはほと んど軟骨はなく eburnation を呈していた. 内側谷の 一部と外側谷部には軟骨が残存していた。視野を妨げ

\footnotetext{
* 福岡大学整形外科 Department of Orthopedic Surgery, Fukuoka University, Fukuoka, Japan
} 


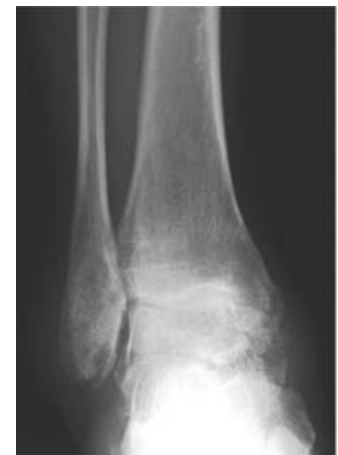

a

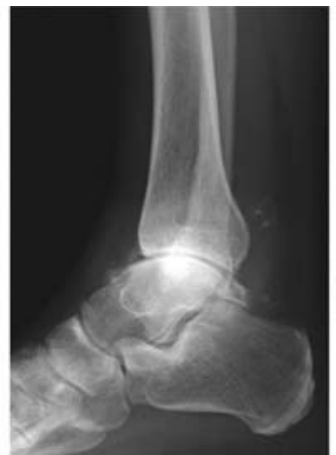

b

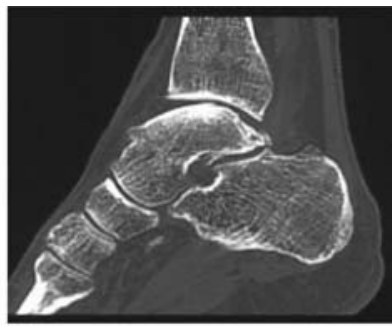

c

図 $1 \mathrm{a}, \mathrm{b}$ : 初診時単純レントゲン, $\mathrm{c}$ ：初診時 $\mathrm{CT}$

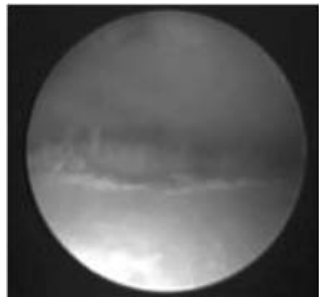

a

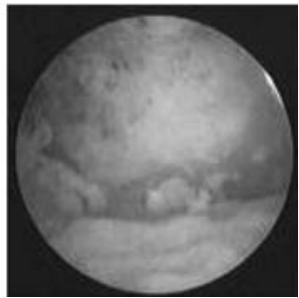

図 2 鏡視像

a 脛骨天蓋と距骨ドーム部はほぼ eburnation を呈している

ｂ＼cjkstart軟骨下骨を掻爬後
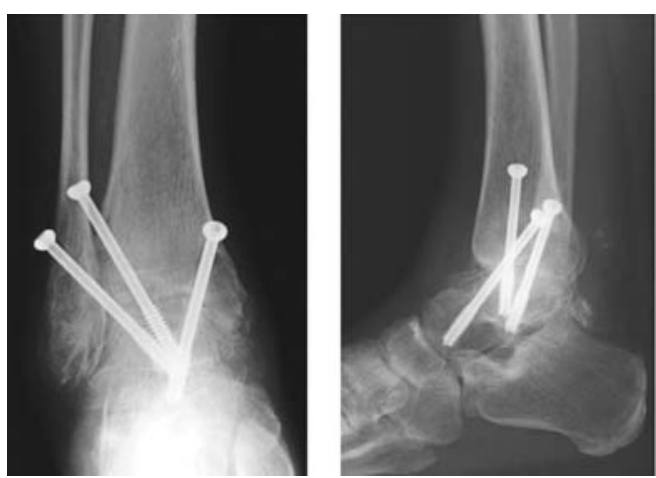

図 4 術後 10 週レントゲン

る滑膜をシェーバー等で切除した後に，鋭爬やアブレー ダーを用いて出血するまで関節面の軟骨下骨を掻爬し た（図 2)。足関節を底背屈 $0^{\circ}$, 軽度外反 ・外転に保 持し, 透視下に $6.0 \mathrm{~mm}$ の CCS 3 本で固定した. 手 術時間は 2 時間 25 分であった. 術後レントゲンを示
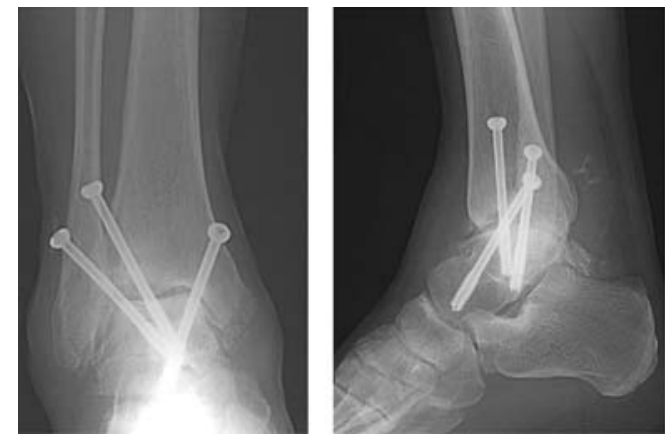

図 3 術後単純レントゲン
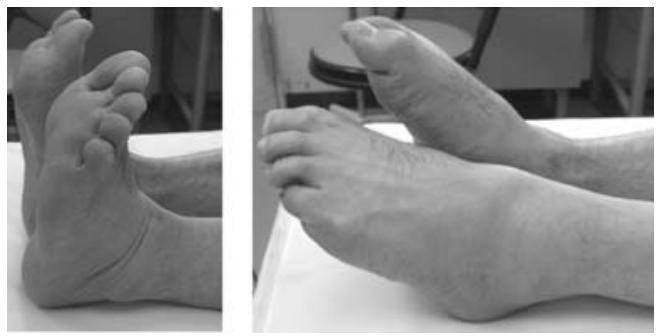

図 5 術後 12 週の足部底背屈の動き（患肢 : 右）

す（図 3). 術後の疼痛はほとんどなく，腫脹も軽度 であった。

術後は, 6 週間のギプス固定と免荷とし, 術後 6 週 よりU字シーネ下に部分荷重を開始した。骨癒合は術 後 10 週で得られた（図 4). 術後 12 週で, 前足部の 代償によって図 5 に示すような足部の動きが可能であ り, 疼痛なく階段昇降も可能となり, 満足度も大変高 かつた。 
考察

一般に末期変形性足関節症の治療は，関節固定術と 人工関節置換術とがある. 50 歳以下の方や活動性の 高い方の場合，また距踵関節に変形のない場合には関 節固定の適応となる.

鏡視下固定術の適応として，足関節の内外反変形が 強くないことがあげられ，内外反 $15^{\circ}$ 以内を適応とし ている報告が多い5). また Ferkel らは，ストレスを かけて内外反変形が矯正されるものと報告している2).

鏡視下法の骨癒合までの平均期間は, Myerson ら 8.7 週 $^{7)}$, Glick ら 9 週 $^{3)}$, 一戸ら 10 週 ${ }^{4)}$, Zvijac ら 8.9 週 ${ }^{9)}$, 倉ら 14.1 週 $^{5)}$, 大饗ら 6.5 週 $^{8)}$, Ferkel ら 11.8 週 ${ }^{2)}$ としており，最近の報告では概ね $8 \sim 10$ 週とした ものが多いようである：ほとんどの著者らが open 法 よりも早いもしくは手技の改善により早くなると報告 している.

鏡視下法での癒合率は, 少数ずつの報告のためばら つきが大きいものの，最近の報告では $86 \%$ から $100 \%{ }^{12) 4-6) 89)}$ と良好である. この理由として，大きく 関節を開き骨膜も剥離する open 法と違い, 鏡視下法 は小切開で侵襲が少ないため血流が保たれるというこ とが考えられる.

合併症は, open 法と同じで偽関節，スクリューヘッ ドなどの刺激, 感染, 骨折, 神経腫等があるが, open 法よりも発生率が少ないとの報告が多い(23)699).

鏡視下法の利点として，低侵襲（術後の疼痛や腫脹 が少ない, 皮膚障害が少ないなど), 癒合期間が短い, 入院期間の短縮などが考えられる。 そのため，特に DM や RA 患者には有用な治療法と思われる．欠点 としては, 高度の変形例には適応がないことや手技が やや煩雑ということがある. 本症例でも手術時間は 2 時間 25 分であった. しかしこれは術者の手技の習熟 や器具の開発, 改良で短縮するものと思われる. 特筆 すべきは，本症例では術後の疼痛は手術翌日にはほぼ
消失し腫脹もほとんどみられなかったことである.

癒合率や合併症に関してはまだ症例数が少なく，ま た適応を限っているために現段階では open 法よりも 有用とは断言できないかもしれないが，低侵襲・術後 の腫脹や疼痛が少ないことは明白であり, 内外反変形 が強くない場合鏡視下法は有用であると思われた.

$$
\text { ま と め }
$$

(1)末期変形性足関節症に対し，鏡視下足関節固定術 を行つた一例を経験した.

(2)術後 10 週で骨癒合が得られた.

(3)内外反変形が少ない場合, 有用な治療法であると 思われた。

(4)今後, 十分な経過観察が必要である.

\section{参 考 文 献}

1) Cameron, S. E., et al.: Arthroscopic arthrodesis of the ankle joint. Arthroscopy, $16: 21-26,2000$.

2) Ferkel, R. D., et al.: Long-term result of arthroscopic ankle arthrodesis. Foot Ankle Int., $26: 275$ 280, 2005.

3) Glick, J. M., et al.: Ankle arthrodesis using an arthroscopic method: long-term follow-up study of 34 cases. Arthroscopy, $12:$ 428-434, 1996.

4）一戸貞文ら：関節鏡視下足関節固定術の経験。関節鏡, 26 : 151-156, 2001.

5）倉 秀治ら：鏡視下足関節固定術の経験. 日足外会誌, $25: 78-82,2004$.

6）箕輪 剛ら：鏡視下足関節固定術の 3 例. 関節鏡, 27 : 107-110, 2002.

7) Myerson, M.S., et al.: Ankle arthrodesis. A comparison of an arthroscopic and an open method of treatment. Clin. Orthop., $268:$ 84-95, 1991.

8）大饗和憲ら：変形性足関節症に対する鏡視下関節固定 術の治療成績. 中部整災誌，47：1025-1026, 2004.

9) Zvijac, J.E., et al.: Analysis of arthroscopically assisted ankle arthrodesis. Arthroscopy, $18: 70-75$, 2002. 